\title{
Green Consumerism: An Empirical Study of Malaysian Government-Linked University
}

\begin{tabular}{ll} 
& $\begin{array}{c}\text { Abdul Rahman Zahari' }{ }^{1} \text { Elinda Esa } \\
\text { 1,2 }\end{array}$ \\
\hline \hline ARTe National Energy University, Malaysia
\end{tabular}

None

Funding:

None

Corresponding Author: Abdul Rahman Zahari, Department of Marketing and Entre Preneur Development, The National Energy University Email: rahman@uniten.edu.my

(c) () () Abdul Rahman Zahari, Elinda Esa

This is an open access article under the CC BY-SA 4.0 international license.

\section{Introduction}

Era 1990s was claimed by many researchers (e.g., McDougall, 1993; Carlson et al., 1996; Brown and Wahlers, 1998 ) as the 'decade of the environment' or the 'Earth decade'. Following this era, social and environmental concerns took on a greater importance for consumer purchasing decisions. Therefore, it has led to the development of a new marketing philosophy called green marketing (McDonagh and Clark, 1995; Peattie and Charter, 1997). The environmental concerns have had a great influence on the marketing strategies of leading firms across numerous industries over the world which include oil and gas, automobile, fast moving consumer goods, cosmetics and personal care, food and health, aviation, utilities etc. and the last decade has also seen a number of green products and services some of which have gained huge acceptance by consumers (Narula and Desore, 2016).

Tseng (2016) had claimed the green consumerism encourages consumers to cultivate an environmentally friendly behavior. For example, if consumers wish to purchase a take-out beverage, they are stimulated to bring their own cups or water bottles rather than use disposable cups. Firms selling take-out beverages are also encouraged to offer price discounts to those who bring their own cups. Green consumer can be defined as a consumer whose purchasing behavior is persuaded by environment concerns (Shrum and McCarty, 1995). They are sincere in their intentions, with a growing commitment to greener lifestyles. The most responsive age group of green consumerisms is tends to be young adults.

Past studies (e.g., Mainieri et al., 1997; Ojala, 2012; Shabani et al., 2013; Yorulmaz, 2016; and Kerret et al., 2016) had mentioned that the greenest consumers were represented by the youth group that aged 17 to 25 years old and women are a key target for greener products because they often make purchases on behalf of men. 
Consumer`s awareness on environmentally friendly products has increased in the past few years based on their growing green brand consciousness. These changes are increasingly being influenced by the firm's policies and practices that affect the quality of the environment and reflect the level of its concern for the community. The green awareness basically influences human behavior in several ways such as reducing consumption, changing wasteful or harmful consumption patterns, and raising preference for environmentally friendly products, selective waste collection, or different forms of protest that may represent the ecological sensibility. These behaviors have led an important mark of green lifestyle and start to advocate environment-friendly consumption to others.

Extensive campaigns conducted by the Malaysian government and corporate sectors to promote the green lifestyles. Malaysian government also has engaged in green technology which promotes green business and green consumerism to improve its ranking in environment ratings. Such campaign by corporate sector can be seen through 'No Plastic Bag Day' which was implemented on every Saturdays by hypermarket chains likes Jusco and Tesco to encourage customers to bring their own bag or alternatively they have option of donating 20 cents if they decide to use the hypermarket's plastic bag. Futhermore, one of the green awareness events jointly observed by the global community is the energy-saving campaign or better known as the Earth Hour. The program has polished the progress of attaining consumers' sustainable lifestyle worldwide. Besides, the universities also conducting many initiatives to promote green lifestyles such as recycle corner, riding bicycle in campus, green day exhibition and competition, no polisterine campaign and many more.

Recently, increasing attention has been paid to the relationships among consumer behavior and the environment (Jain and Kaur, 2006; do Paco et al., 2009; Awad, 2011; Shabani et al., 2013; and Yorulmaz, 2016). Such consideration has been manifested in two ways: there has been an increase in public awareness about environmental aspects, and it indicates an increase in the evidence of environmental responsibility or green marketing activities. Despite of reaching global awareness, Compendium of Environment Statistics (2015) has reported the emission of pollutants to the atmosphere from power plant and motor vehicles in 2014 are increased by 20 per cent and 14.3 per cent respectively in Malaysia as compared to 2010. Besides, in 2014, the quantity of waste generated was slightly decreased to 1.67 million tonnes as compared to 1.88 million tonnes in 2010 .

Moreover, household e-waste such as washing machine, refrigerator, air-conditioner, television, computer, hair dryer, printer, oven, blender and hand phone were also affected the environment upon the end of the life. According to Perunding Good Earth Sdn. Bhd. (2009), the average of household e-waste in Malaysia was 700,000 tonnes. In order to reduce the causes of pollutions and damage of environments, one of strategy is to encourage consumers to purchase electronic products that are environmentally friendly (Ngo, 2008). It is importance to cater this issue seriously through categorizing the types of green consumers relatively to university students because very scarce studies have discussed on how the green consumerism is being labeled (Tanner and Kast, 2003; Lee, 2008; Cheah, 2009). Lee (2008) has added the green marketing studies in Asian countries are relatively less as compared to Western countries.

\subsection{Green Consumerism}

In general, the green consumerism can be defined as one who adopts environmentally friendly behavior and/or who purchases green products over the standard alternatives. The green consumers are more internally controlled as they believe that an individual consumer can be effective in environmental protection (Shamdasani et al., 1993). They feel that the job of environmental protection should not be burdened to the government, business, environmentalists, and scientists only because they as consumers can also play a part. They are also less dogmatic and more open-minded or tolerant toward new products. Their open-mindedness helps them to accept green products and behaviors, more readily.

Furthermore, Mostafa (2007) defined green purchase behaviour as an environmentally friendly buying behaviour or the consumption of products that benefits the environment, conservable, recyclable, responsive and sensitive to the concern of ecological matters. Chan (2001) defined it as environmentally friendly behaviour expressed by consumers in showing their interest towards the environment whereas Nik Abdul Rashid (2009) described it as the probability and willingness of individuals who give preference to products that contain features that are environmentally friendly when compared to the purchase of other traditional products. Green consumerism is, for a significant portion of the Western industrial population, an accessible way to engage in pro-environmental, sustainable behavior (MacEachern, 2008).

\subsection{Types of Green Consumerism}

Prior study by Ginsberg and Bloom (2004) divided the green consumers into few categories based on environmentally friendly behavior. The first category is called pure green militant or true blue green. This catogory of consumers has strong environmental values and intensive desire to participate in activities and organizations supporting the environment. They intensively refuse to buy the products from manufacturers 
unresponsive to the environment (Shabani et al., 2013). Next is waste management category where their main areas of concerns are water, electricity, and communication services. They treated the utilities with importance so that society may have clean and adequate water, constant energy flow at homes and offices and constant communication for effective business. Additionally, consumers who are willing to pay a higher price to use the green products are considered as the green churning and green price forfeiter.

With regard to environmentally friendly product, consumers always select green goods among alternative goods when intended goods is better or at least equal to alternative goods in terms of subjective and functional characteristics (Ginsberg and Bloom, 2004). There are more than 80 percent of Thai, Malaysian and Korean consumers who are willing to pay premium price to purchase environmental product (Dunlap and Scarce 1991; Lung 2010). International Energy Agency (2016) defined the energy efficiency is a way of managing and restoring the growth in energy consumption. Something is more energy efficient if it delivers more services for the same energy input, or the same services for less energy input. More importantly, they have strong support to the use of renewable energy.

Paper in today's world is used in everyday life for countless purposes so its consumption has been increasing. In order to solve the problem of sourcing raw material for paper production, it is better to develop technologies for sustainable recycling rather than sustainable forestry. Thus, separating all the components of wastepaper except for fibers using the most economical and environmentally friendly methods and recycling are crucially important (Karademir et al., 2012). The interest for collecting wastepaper and recycling them to be used in paper production has been increasing globally. With recycling, used products gain economic value again (Sengul, 2010).

\subsection{Green Consumer Segmentation}

This study is only used demographic segmentation to identify the consumption patterns of university students. Prior studies (e.g. Laroche et al., 2001; do Paco et al., 2009; do Paco and Paposo, 2010; Akehurst et al., 2012; Kaufmann et al., 2012; Goh and Abdul Wahid, 2015) have been explored the variables of demographic criteria such as age, gender, education, and income with environmental sensitivity. As well as more concentrated with publics' perceptions on green products. In light of the above arguments, the focus of this study is to examine the awareness of university students towards green products. To assess the demographic effects on green consumerism, this study has provided the research framework as shown in Figure 1.

\begin{tabular}{|c|c|}
\hline $\begin{array}{ll}\text { Demographic Factors } \\
\text { - } & \text { Gender } \\
\text { - } & \text { Age } \\
\text { - } & \text { Race } \\
\text { - } & \text { Hometown area }\end{array}$ & $\begin{array}{l}\text { Green consumerism } \\
\text { - } \quad \text { Waste management } \\
\text { - } \quad \text { Pure green militant } \\
\text { - } \quad \text { Green churning and green price } \\
\quad \text { forfeiter }\end{array}$ \\
\hline
\end{tabular}

Figure 1. Research Framework

From the Figure 1, the research framework is incorporating demographic factors namely gender, age, race, hometown area, year of study, and study program as the observed factors for five groups of green consumerism namely waste management, pure green militant, green churning and green price forfeiter, energy reducer users, and paper recycler users. The variables were selected because it suited with the previous studies of green consumer conducted in United States, European, and Asian (Nair, 2015). The proposed hypotheses are as follows:

H1: There is a significant difference between gender and waste management, pure green militant, green churning and green price forfeiter, energy efficiency users, and paper recycler users.

$\mathrm{H} 2$ : There is a significant difference between age and waste management, pure green militant, green churning and green price forfeiter, energy efficiency users, and paper recycler users.

H3: There is a significant difference between race and waste management, pure green militant, green churning and green price forfeiter, energy efficiency users, and paper recycler users.

H4: There is a significant difference between hometown area and waste management, pure green militant, green churning and green price forfeiter, energy efficiency users, and paper recycler users.

H5: There is a significant difference in year of study with waste management, pure green militant, green churning and green price forfeiter, energy efficiency users, and paper recycler users.

H6: There is a significant difference in study program with waste management, pure green militant, green churning and green price forfeiter, energy efficiency users, and paper recycler users. 
This study provides ideas for decision-makers in the field of marketing to adopt new marketing practices. Additionally, understanding the demographic characteristics of green consumerism can help the entrepreneurs to explore the environmental market and getting more likely prospects. Therefore, the current study aims to achieve two objectives; (i) to rank the green consumerism among university students, and (ii) to examine the differences of between groups i.e., gender, age, race, hometown area, year of study, and study program with green consumerism groups.

The remainder of paper is structured as follows. Section 2, research method that outline the sample selection and the research techniques. The third part is to discuss the results and analysis and the last part is the conclusion.

\section{Method}

This research was conducted in one of the government-linked universities (GLUs) in Malaysia. A total of 250 respondents were involved in this study using the stratified sampling method. Only undergraduate students were participated in this study. The completed questionnaires yielded a response rate of 91.0 per cent. Respondents were selected from various programmes i.e. accounting, finance, international business, human resource management, marketing, and entrepreneur development. Furthermore, the current study used a personally administered questionnaire survey.

The questionnaire used is consisted of two parts: the first part is the types of green consumerism; and the second part is pertaining to the respondent's profile. There are 27 items were used to measure the group of green consumerism among university students. The portions of items are: pure green militant (8 items); waste management (3 items); green churning and green price forfeiter ( 9 items); energy reducer (4 items); and paper recycles (3 items). These items were adapted from Juwaheer (2005), Joos et al., (1999), Morrissey and Browne (2004), Ginsberg and Bloom (2004) and Sujipto et al., (2008). The survey question has used 6-point Likert scale, ranging from 1 (strongly disagree) to 6 (strongly agree).

In addition, six questions were used to explain the profiles of respondents. Among the questions are; gender, age, race, hometown area, year of study, and study programme. Two additional questions were set up to identify the experience of students in buying green products and types of purchased green products. The completed instrument was pre-tested by 20 respondents. Based on the feedback attained from these respondents, the questionnaire was subsequently refined. Data obtained from the personally administered questionnaire was analyzed using some statistical tools contained in the statistical software. i.e., 'Statistical Package of Social Science' (SPSS) 21.0 for Windows. Besides descriptive analysis, three other different statistical analyses also were used in this study includes reliability test, independent-samples t-test and analysis of variance (ANOVA).

\section{Results and Discussion}

Table 1 presents the respondent's profile. Out of 250 respondents, 31.2 per cent were male and 68.8 per cent were female respondents. Also, 37.6 per cent of respondents are 18-21 years old and majority of them with 62.4 per cent are above 21 years old. According to ethnicity, the majority of respondents were Malays with 59.6 per cent, followed by Indian with 32.8 per cent, Chinese with 6.4 per cent, and others with 1.2 per cent. Most of the respondents ( 52 per cent) are originated from urban areas, followed by those who lived in suburban with 37.6 per cent, and rural areas only representing 10.4 per cent. About 40.4 per cent respondents were from year 2 students, 36 per cent were third year students, 16 per cent were first year student and only 7.6 per cent were fourth year students.

With respect to study program, 27.6 per cent of respondents were form Human Resource Management degree program, 21.2 per cent from Bachelor of Accounting, 17.6 per cent from Marketing program, 16.4 per cent from Bachelor of Finance, 9.2 per cent from Entrepreneur Development program and followed by International Business program with 8 per cent. With regard to green purchase experienced, most of the respondent (92.4 per cent) was involved in the buying process. Only 7.6 per cent have no green purchase experience.

Stationeries and office supplies are the top-ranking green products bought by students with 41.2 per cent. Then, learning products with 32.8 per cent as well as 31.2 per cent of them bought green household goods and 28.4 per cent purchased green appliances and electronics. Two other types of green product category i.e., beauty products and foods and beverages have shared the same percentage with 26.4 per cent. 
Table 1. Respondents' profile

\begin{tabular}{|c|c|c|c|}
\hline Item & Description & Frequency $(n=250)$ & Percentage \\
\hline \multirow[t]{2}{*}{ Gender } & Male & 78 & 31.2 \\
\hline & Female & 172 & 68.8 \\
\hline \multirow[t]{2}{*}{ Age } & 18 to 21 years old & 94 & 37.6 \\
\hline & Above 21 years old & 156 & 62.4 \\
\hline \multirow[t]{4}{*}{ Race } & Malay & 149 & 59.6 \\
\hline & Chinese & 16 & 6.4 \\
\hline & Indian & 82 & 32.8 \\
\hline & Others & 3 & 1.2 \\
\hline \multirow[t]{3}{*}{ Hometown } & Urban & 130 & 52.0 \\
\hline & Suburban & 94 & 37.6 \\
\hline & Rural & 26 & 10.4 \\
\hline \multirow[t]{4}{*}{ Year of study } & Year 1 & 40 & 16.0 \\
\hline & Year 2 & 101 & 40.4 \\
\hline & Year 3 & 90 & 36.0 \\
\hline & Year 4 & 19 & 7.6 \\
\hline \multirow[t]{6}{*}{ Study program } & Accounting & 53 & 21.2 \\
\hline & Finance & 41 & 16.4 \\
\hline & Marketing & 44 & 17.6 \\
\hline & Human Resource Management & 69 & 27.6 \\
\hline & Entrepreneur Development & 23 & 9.2 \\
\hline & International Business & 20 & 8.0 \\
\hline \multirow{2}{*}{$\begin{array}{l}\text { Green } \\
\text { experience }\end{array}$} & Yes & 231 & 92.4 \\
\hline & No & 19 & 7.6 \\
\hline \multirow{6}{*}{$\begin{array}{l}\text { Types of green product } \\
\text { bought by students }\end{array}$} & Stationery and office supplies & 103 & 41.2 \\
\hline & Cleaning products & 82 & 32.8 \\
\hline & Foods and beverages & 66 & 26.4 \\
\hline & Appliances and electronics & 71 & 28.4 \\
\hline & Beauty products & 66 & 26.4 \\
\hline & Household goods & 78 & 31.2 \\
\hline
\end{tabular}

Descriptive analysis was conducted to answer the first objective of the study. This analysis is used to identify the mean scores for each individual and factor items. The mean scores for individual and factor items are ranged from 3.25 to 4.33 and 3.42 to 4.11 respectively. Energy efficiency users is recorded the highest average mean scores (4.11) and being ranked as number one. Then it was followed by green churning and green price forfeiter with 4.03. The third ranked is pure green militant group with average mean scores of 3.68. Waste management and paper recycle users are ranked at number four and five respectively with the scores of 3.57 and 3.42. The results have shown that the respondents in this study are more towards the energy efficiency users, and it may be reflected with university that they have enrolled. Therefore, more awareness should be emphasized to the other groups of green consumerisms.

The next analysis is to examine the results of reliability test. As shown in Table II, the Cronbach alpha value for each of the green consumerism group is ranged from 0.715 to 0.870 . The values should be above 0.7 as suggested by DeVellis (2003). Pavot et al., (1991) also added that pure green militant scale has good internal consistency with a Cronbach alpha coefficient reported of 0.87 . 
Table 2. Descriptive and reliability results

\begin{tabular}{|c|c|c|c|c|c|}
\hline Pure Green Militant & M & SD & $\mathrm{AM}$ & $\mathrm{CA}$ & Rank \\
\hline $\begin{array}{l}\text { I have convinced members of my family or friends not to buy some } \\
\text { products which are harmful to the environment. }\end{array}$ & 4.15 & 1.28 & \multirow{8}{*}{3.68} & \multirow{8}{*}{0.87} & \multirow{8}{*}{3} \\
\hline I use a recycling enter or in some way recycle some of my household trash. & 3.78 & 1.24 & & & \\
\hline I use a low phosphate detergent (or soap) for my laundry. & 3.56 & 1.37 & & & \\
\hline I do not buy product in aerosol containers. & 3.54 & 1.21 & & & \\
\hline I have purchased products because they cause less pollution. & 3.94 & 1.24 & & & \\
\hline $\begin{array}{l}\text { I have replaced light bulbs in my home with those of smaller wattage so } \\
\text { that I will conserve on the electricity use. }\end{array}$ & 3.65 & 1.29 & & & \\
\hline I try only to buy products that can be recycled. & 3.55 & 1.25 & & & \\
\hline I always try to use electric appliances before 9 a.m. and after 9 p.m. & 3.29 & 1.34 & & & \\
\hline \multicolumn{6}{|l|}{ Waste Management } \\
\hline I would like to take hazardous waste to collection site. & 3.25 & 1.24 & \multirow{3}{*}{3.57} & \multirow{3}{*}{0.72} & \multirow{3}{*}{4} \\
\hline I try compost yard waste. & 3.26 & 1.19 & & & \\
\hline I buy products in packages that can be refilled. & 4.20 & 1.32 & & & \\
\hline
\end{tabular}

Green Churning and Green Price Forfeiter

If I understand the potential damage to the environment that some products can cause, I do not purchase these products.

$4.28 \quad 1.27$

When there is a choice, I always choose that product which contributes to the least amount of pollution.

$4.24 \quad 1.26$

I have switched products for ecological reasons.

$3.84 \quad 1.24$

I have tried very hard to reduce the amount of electricity I use.

$4.33 \quad 1.23$

I will not buy product if the company sells it is ecologically irresponsible.

When I have choice between equal products, I always purchase the one which is less harmful to other people and the environment.

$\begin{array}{lllll}4.16 & 1.24 & 4.03 & 0.83 & 2\end{array}$

If I like something and I want to purchase it, price is not a concern.

$4.31 \quad 1.19$

In general, if a non-green product cost RM10.75, I will pay RM12.90 for a green product of the same kind.

$3.82 \quad 1.39$

$3.74 \quad 1.26$

I read labels to see if contents are environmentally safe.

$4.27 \quad 1.16$

Energy Efficiency Users

I try to buy energy-efficient household appliances.

$3.93 \quad 1.28$

I normally make a conscious effort to limit my use of products that are made of or use scarce resources.

3.981 .15

Whenever possible, I buy products packaged in reusable containers.

$4.23 \quad 1.28$

I have purchased light bulbs that were more expensive but saved energy.

$3.96 \quad 1.34$

Paper Recycle Users

I make every effort to buy paper from recycled paper.

$3.48 \quad 1.24$

I buy toilet paper made from recycled paper.

$\begin{array}{lllll}3.39 & 1.37 & 3.42 & 0.78 & 5\end{array}$

I buy paper towels made from recycled paper.

$3.40 \quad 1.39$

Note: Mean (M); Average mean (AM); Standard deviation (SD); and Cronbach Alpha (CA).

The second objective of this study is to examine the differences between groups i.e., gender, age, race, hometown area, year of study, and study program with five classes of youth green consumerism. To test the differences between groups, two types of tests such as independents- samples t-test and analysis of variance (ANOVA) were conducted. Two series of independent-samples t-test were conducted to compare the 
differences between groups of gender and age with five groups of green consumerism namely waste management, pure green militant, green churning and green price forfeiter, energy efficiency users, and paper recycler users. The results show in Table III stated that the gender (male and female) has significant differences with two groups of green consumerisms i.e., waste management, $\mathrm{p}=0.021$ (two-tailed), and green churning and green price forfeiter, $p=0.019$ (two-tailed). However, the magnitude of the difference in the eta squared is small for the groups of waste management and green churning and green price forfeiter. Whereas other types of green consumerism such as pure green militant, energy reducer and paper recycler show no differences with the gender.

In view to the differences between groups of age with five groups of green consumerisms, the result indicates that only paper recycler users have significant different by age category (18 to 21 years old and above 21 years old).

There were no significant differences between groups of age with the cluster of waste management, pure green militant, green churning and green price forfeiter, and energy efficiency users. Paper recycler has contributed $p=0.016$ (two-tailed) for age category. The magnitude of the difference in the eta squared is small for the factor of paper recycler users. Therefore, hypotheses $\mathrm{H} 1$ and $\mathrm{H} 2$ are accepted, and the results is in line with the previous studies conducted by Jain and Kaur, (2006), D'Souza et al., (2006), do Poco et al., (2009), Awad, (2011), Boztepe, (2012), Kauffman et al., (2012), Fisher et al., (2012), Shabani et al., (2013) and Yorulmaz, (2016).

Table 3. T-Test results on demographic factors (Gender and Age)

\begin{tabular}{|c|c|c|c|c|c|c|}
\hline \multirow[b]{2}{*}{ Classification of green consumerism } & \multicolumn{3}{|l|}{ Gender } & \multicolumn{3}{|l|}{ Age } \\
\hline & $\begin{array}{l}\text { Sig. } \\
\text { (2-tailed) }\end{array}$ & $\begin{array}{l}\text { Eta } \\
\text { Squared }\end{array}$ & $\begin{array}{l}\text { Effect } \\
\text { size }\end{array}$ & $\begin{array}{l}\text { Sig. } \\
\text { (2-tailed) }\end{array}$ & $\begin{array}{l}\text { Eta } \\
\text { Squared }\end{array}$ & $\begin{array}{l}\text { Effect } \\
\text { size }\end{array}$ \\
\hline Waste management & 0.021 & 0.021 & Small & 0.574 & & \\
\hline Pure green militant & 0.067 & & & 0.841 & & \\
\hline Green churning and green price forfeiter & 0.019 & 0.022 & Small & 0.423 & & \\
\hline Energy efficiency users & 0.058 & & & 0.961 & & \\
\hline Paper recycler users & 0.170 & & & 0.045 & 0.016 & Small \\
\hline
\end{tabular}

Next, a series of ANOVA test were used to assess the differences of groups i.e., race, hometown area, year of study, and study program with five classes of youth green consumerism. A one-way between groups of ANOVA was conducted to examine the impact of race on waste management, pure green militant, green churning and green price forfeiter, energy efficiency users, and paper recycler users. Subjects were divided into four groups such as Malay, Chinese, Indian and others. There was a statistically significant difference at the $p<0.05$ level in waste management and energy reducer consumerism. Despite reaching statistical significance, the effect size, calculated using eta squared were 0.013 and 0.009 and considered as a small effect. With regards to hometown area, this subject was divided into three categories namely urban, suburban, and rural area.

The results in Table IV indicates that there are no significant differences of hometown between five types of green consumerism. The same findings were recorded for study program. The result has revealed that various academic programs have no significant difference with five classes of green consumerism. However, there are significant difference of groups (year of study) with groups of green consumerisms. There was a statistically significant difference at the $p<0.05$ level in waste management, pure green militant, green churning and green price forfeiter, and energy efficiency users. In spite of reaching statistical significance, the effect size, calculated using eta squared were 0.001 and 0.002 and thus can be categorized as a small effect. To summarise, hypotheses $\mathrm{H} 3$ and $\mathrm{H} 5$ were accepted while $\mathrm{H} 4$ and $\mathrm{H} 6$ were not accepted. The results are similar to past study conducted by Fisher et al., (2012) but insimilar to previous studies by Jain and Kaur, (2006) and Awad, (2011).

Table 4. ANOVA results on demographic factors (race, hometown, year of study and study program)

\begin{tabular}{llllll}
\hline $\begin{array}{l}\text { Green consumerism } \\
\text { group }\end{array}$ & $\begin{array}{l}\text { Waste } \\
\text { management }\end{array}$ & $\begin{array}{l}\text { Pure green } \\
\text { militant }\end{array}$ & $\begin{array}{l}\text { Green churning and } \\
\text { green price forfeiter }\end{array}$ & $\begin{array}{l}\text { Energy } \\
\text { efficiency }\end{array}$ & $\begin{array}{l}\text { Paper } \\
\text { recycler }\end{array}$ \\
\hline Race (Sig.) & 0.023 & 0.297 & 0.203 & 0.013 & 0.263 \\
Race (eta squared) & 0.013 & & & 0.009 & \\
Effect size & Small & & & Small & \\
\hline Hometown (Sig.) & 0.093 & 0.318 & 0.096 & 0.243 & 0.352 \\
\hline
\end{tabular}




\begin{tabular}{|c|c|c|c|c|c|}
\hline Year of study (Sig.) & 0.026 & 0.043 & 0.004 & 0.002 & 0.364 \\
\hline $\begin{array}{l}\text { Year of study } \\
\text { (eta squared) }\end{array}$ & 0.001 & 0.001 & 0.001 & 0.002 & \\
\hline Effect size & Small & Small & Small & Small & \\
\hline Study program (Sig.) & 0.693 & 0.154 & 0.065 & 0.087 & 0.261 \\
\hline
\end{tabular}

\section{Conclusion}

The policymakers, green marketers and entrepreneurs could have an opportunity to identify which demographic factors that have significance differences between groups with five types of green concumerism namely waste management, pure green militant, green churning and green price forfeiter, energy efficiency users, and paper recycler users in the context of university students. Understanding the ranking of green consumerism is very importance because it will benefit the policymakers, green marketers, entrepreneurs, and university to futher focus in promoting green lifestyles among graduates.

There are six demographic variables were used to examine the differences of the groups with five types of green consumerism by using two different analyses. The results have indicated that four demographic variables such as gender, age, race and year of study have shown significance differences with the class of green consumerism. However, the eta-squared values have explained the small effect size. Two variables of demographic i.e., hometown and study program have no significance diffecences with the group of green consumerisms. To sum up, the majority of demographic variables tested in this study have shown significance differences with the group green consumerism. Thus, the policymakers, green marketers and entrepreneurs should have more potential to develop appropriate the right green marketing strategies for this target market.

Since this study only focused to one of GLUs in Malaysia, therefore in future, the researcher can expand to investigate the effects of demographics with the types of green consumerism from other universities. With greater sample sizes from different universities, the policymakers, green marketers, and entrepreneurs could have benefits from the comparative study that will be conducted in the future. Besides, the additional variables of socio demographics could also possibly be added for the future research.

\section{Acknowledgement}

The authors would like to appreciate Nur Shafiqah Ramlan, Kaliyamah Arunasalam and Aberamy Sundar for helping us to collect the data.

\section{References}

Akehurst, G., Afonso, C., \& Gonçalves, H.M. (2012). Re-examining green purchase behaviour and the green consumer profile: new evidence. Management Decision, 50(5), 972-988.

Awad, T.A. (2011). Environmental segmentation alternatives: buyers' profiles and implications. Journal of Islamic Marketing, 2(1), 55-73.

Boztepe, A. (2012). Gren marketing and its impact on consumer buying behavior. European Journal of Economic and Political Studies, 5(1), 5-21.

Brown, J. \& Wahlers, R. (1998). The environmentally concerned consumer: An exploratory study. Journal of Marketing Theory and Practice, 6(2), 39-47.

Carlson, L., Grove, S., Kangun, N., \& Polonsky, M. (1996). An international comparison of environmental advertising: substantive versus associative claims. Journal of Macromarketing, 16(2), 57-68.

Chan, R. Y. K. (2001). Determinants of Chinese consumers' green purchase behaviour. Psychology and Marketing, 18(4), 389-413. Retrieved from http://dx.doi.org/10.1002/mar.1013

Cheah, C. M. (2009). A study on consumers green purchasing intention (Unpublished master's thesis). Malaysia: College of Business, Universiti Utara Malaysia.

Compendium of Environment Statistics (2015). Retrieved from https://www.statistics.gov.my/

D’Souza, C., Taghian, M., Lamb, P., \& Peretiatkos, R. (2006). Green products and corporate strategy: An empirical investigation. Society and Business Review, 1(2), 144-157. DeVellis, R.F. (2003). Scale development: Theory and applications (2nd ed.), Thousand Oaks, California: Sage.

do Paço, A.M.F., \& Raposo, M.L.B. (2010). Green consumer market segmentation: empirical findings from Portugal. International Journal of Consumer Studies, 34(4), 429-436.

do Paço, A.M.F., Raposo, M.L.B., \& Filho, W.L. (2009). Identifying the green consumer: A segmentation study. Journal of Targeting, Measurement and Analysis for Marketing, 17(1), 17-25. 
Dunlap, R., \& Scarce, R. (1991). Environmental problems and protections. Public Opinion Quarterly, 55, 651672.

Fisher, C., Bashyal, S., \& Bachman, B. (2012). Demographic impacts on environmentally friendly purchase behaviors. Journal of Targeting, Measurement and Analysis for Marketing, 20(3/4), 172-184.

Ginsberg, J.M., \& Bloom, P.N. (2004). Choosing the right green-marketing strategy. MIT Sloan Management Review, 46(1), 79-88.

Goh, Y.N., \& Abdul Wahid, N. (2015). A review on green purchase behaviour trend of Malaysian consumers. Asian Social Science, 11(2), 103-110.

International Energy Agency (2016). Retrieved from https://www.iea.org/topics/energyefficiency/

Jain, S., \& Kaur, G. (2006). Role of socio-demographics in segmenting and profiling green consumers: An exploratory study of consumers in India. Journal of International Consumer Marketing, 18(3), 107117.

Joos, W., Carabias, V., Winistoerfer, H., \& Stuecheli A. (1999). Social aspects of public waste management. Switzerland Waste Management, 19, 417-425.

Juwaheer, T.D. (2005). An emerging environmental market in Mauritius: myth or reality? World Review of Entrepreneurship, Management and Sustustainability Development, 1(1), 57-74.

Karademir, A., Karahan, S., Imamoglu, S., Ertas, M., Aygan, A., Aydemir, C., \& Pesman, E. (2012). Paper recycling of enzyme and ultrasonic energy use. History Culture and Art Research Magazine (Consuption Society and Environment), 1(4), 280-297.

Kaufmann, H. R., Panni, M. F. A. K., \& Orphanidou, Y. (2012). Factors affecting consumers' green purchasing behaviour: An integrated conceptual framework. Amfiteatru Economic, 15(31), 50-69. Retrieved from http://www.amfiteatrueconomic.ase.ro/english/archive.html

Kerret, D., Orkibi, H., \& Ronen, T. (2016). Testing a model linking environmental hope and self-control with students' positive emotions and environmental behavior. The Journal of Environmental Education, 47 (4), 307-317.

Laroche, M., Bergeron, J., \& Barbaro-Forleo, G. (2001). Targeting consumers who are willing to pay more for environmentally friendly products. Journal of Consumer Marketing, 18(6), 503-520.

Lee, K. (2008). Opportunities for green marketing: Young consumers. Marketing Intelligent and Planning, 26, 573-586.

Lung, S. (2010). Green consumerism-the way to effectively differentiate your products in Asia-Pacific market (online article). Retrieved from http://ezinearticles.com/?Green-Consumerism---The-Way-toEffectively-Differentiate-Your-Products-in-Asia-Pacific Market\&id=4875312. 32

MacEachern, D. (2008). Big green purse: Use your spending power to create a cleaner. Penguin: Greener World, 436.

Mainieri, T., Barnett, E., Valdero, T.R., Unipan, J.B., \& Oskamp, S. (1997). Green buying: The influence of environmental concern on consumer behaviour. Journal of Social Psychology, 137(2), 189-204.

McDonagh, P., \& Clark, A. (1995). Corporate communications about sustainability: Turning clever companies into enlightened companies. Greener Management International, 11, 49-62.

McDougall, G. (1993). The green movement in Canada: Implications for marketing strategy. Journal of International Consumer Marketing, 5(3), 69-87.

Morrissey, A.J., \& Browne, J. (2004): Waste management models and their application to sustainable waste management. Waste Management, 24, 297-308.

Mostafa, M. M. (2007). Gender differences in Egyptian consumers green purchase behaviour: The effects of environmental knowledge, concern and attitude. International Journal of Consumer Studies, 31, 220-229. Retrieved from http://dx.doi.org/10.1111/j.1470-6431.2006.00523.x

Nair, P.B. (2015). Profiling green consumer characteristics: an eternal quandary. Journal of Advanced Science, 3(2), 174-178.

Narula, S.A., \& Desore, A. (2016). Framing green consumer behaviour research: opportunities and challenges. Social Responsibility Journal, 12(1), 1-22.

Ngo, K. (2008). The influence of environmental claims on consumers' willingness to purchase. Retrieved from http://nature.berkeley.edu/ 
Nik Abdul Rashid, N. R. (2009). Awareness of eco-label in Malaysia's green marketing initiative. International Journal of Business and Management, 4(8), 132-141. Retrieved from http://dx.doi.org/10.5539/ijbm.v4n8p132

Ojala, M. (2012). Hope and climate change: The importance of hope for environmental engagement among young people. Environmental Education Research, 18, 625-642.

Pavot, W., Diener, E., Colvin, C. R., \& Sandvik, E. (1991). Further validation of the satisfaction with life scale: Evidence for the cross-method convergence of well-being measures. Journal of Personality Assessment, 57, 149-161.

Peattie, K., \& Charter, M. (1997). Green marketing. In: P. McDonagh and A. Prothero (eds.) Green Management. New York: The Dryden Press, 388-412.

Perunding Good Earth. (2009). The e-waste inventory project in Malaysia. Department of Environment, Malaysia \& EX- Corporation, Japan.

Sengul, U. (2010). Recycling of wastes and reverse logistics. Paradoks, Journal of Economics, Sociology and Policy, 6(1), 73-86

Shabani, N., Ashoori, M., Taghinejad, M., Beyrami, H., \& Fekri, M.N. (2013). The study of green consumers' characteristics and available green sectors in the market. International Research Journal of Applied and Basic Sciences, 4(7), 1880-1883.

Shamdasani, P., Gloria, O. C.L., \& Daleen, R. (1993). Exploring green consumers in an oriental culture: Role of personal and marketing mix factors. Advances in Consumer Research, 20, 491.

Shrum, L.J., \& McCarty, J.A. (1995). Buyer characteristics of the green consumer and their implications for advertising strategy. Journal of Advertising, 24(2), 71-83.

Sutjipto, E.R., Li, K., Pongpattanasuegsa, S. \& Nazhad, M.M. (2008). Effect of recycling on paper properties. TAPPSA Journal. Retrieved from http://www.tappsa.co.za/archive3/index.html.

Tanner, C., \& Kast, S. W. (2003). Promoting sustainable consumption: determinants of green purchases by Swiss consumers. Psychological Marketing, 20, 883-902.

Tseng, C.H. (2016). The effect of price discounts on green consumerism behavioral intentions. Journal of Concumer Behaviour, 15(4), 325-334.

Yorulmaz, U.U. (2016). Green consumer in green marketing. International Journal of Online Marketing Research, 2(1), 14-21. 